\title{
Analysis of the Accuracy of Different Geodesic Measurements Methods for Measuring Roads
}

\section{Donatas Rekus*, Vilma Kriaučiūnaitè-Neklejonovienè}

Kaunas University of Technology, Faculty of Civil Engineering and Architecture Studentu st. 48-418, LT-51367 Kaunas, Lithuania

*Corresponding author: donatas.rekus@ktu.lt

$\Gamma$ crossef $h$ ttp://dx.doi.org/10.5755/j01.sace.23.2.21134

Roads, railroads and streets are one of the most important infrastructure, so it is very important rightly construct and to make control geodesic pictures of them. In order to qualitatively and effectively carry out the following operations, it is necessary to assess the methods (advantages and disadvantages) used for these works. The work describes the usage of the measurements devices, their specifications, data analysis and comparison with the most efficient device. Railway tracks require more thorough maintenance and analysis than regular roads for cars. Defects are here noticed and recorded by using special equipment. Construction of railway roads and their exploitation requires optimal accuracy and monitoring of surveying. It is related to maximum allowed speed of trains, the environment, transport and human safety. Their monitoring needs to be improved by applying geodetic devices for surveying. Comparing analogous surveying conducted using EM140 machine with that of geodetic equipment, one can see the advantage of geodetic surveying. Technical gaps in the surveying process, data storage and procession were evaluated as well. It was discovered that maintenance and monitoring works should be pursued more frequently using high accuracy geodetic equipment. The main aim of this article is to evaluate differences of the technological process and control technology by conducting geodetic investigation in railway objects.

Keywords: electronic tacheometer, GNSS receiver, railway, geodetic surveying.

Roads, railway roads and streets are one of the most important infrastructure, so it is very important rightly construct and to make control geodesic pictures of them. In order to qualitatively and effectively carry out the following operations, it is necessary to assess the methods (advantages and disadvantages) used for these works.

An important moment is observation and evaluation of railway road condition. Railway tracks require more accurate maintenance and analysis than regular roads for cars. Defects in regular roads can be noticed and recorded by simple inspection without using any special equipment but rather marking it in the survey. As Š. Prokopimas states (2017), quality requirements for arranging railway infrastructure objects are always included in the primary conditions of the project and they must be observed within limits of allowed deviations and tolerance throughout the whole process of construction and exploitation (works of rubber ballast compaction and accurate railway road tamping to the project position). Precise arrangement of railway roads in the project position,

\section{Introduction}

Analysis of the Accuracy of Different Geodesic Measurements Methods for Measuring Roads

Received 2018/09/24

Accepted after revision 2018/11/03

_ـ

\section{JSACE $2 / 23$}


observing the deadlines of works by maintaining high quality indices, etc. call for contemporary surveying and observation technologies allowing functional and immediate inspection and regulation of railway road condition throughout construction and exploitation period.

The research into organization and optimization of railway road inspection and repair was analysed by A. R. Andrade (2008), S. Jovanovic (2004), C. A. Grimes (1995) D. Larson (2004), B. Aursudkij, G. R. McDowell, A. C. Collop (2009) and other numerous authors. I. Gailienè, I. Podagelis (2008) designed very important evaluation where strength characteristics of Lithuanian railway lines upper construction were defined. J. Lackenby (2006), B. Aursudkij (2007), S. F. Brown et al. (2004), Skrinskas et al. (2010) conducted relevant research. Contemporary construction and exploitation of railway infrastructure objects requires maximum accuracy of surveying in order to increase the speed of trains. Exploitation of modern railway roads requires high responsibility of works and more careful monitoring.

The article deals with construction, regulation and monitoring works of railway roads.

Research object: Investigation and control geodetic works in the railway territory

Aim and objectives:

The aim is to evaluate differences of the technological process and control technology by conducting geodetic investigation in railway objects.

1. Analyse and evaluate differences, assumptions and occurring problems of the technological process by conducting railway geometric investigations.

2. Define optimal frequency of geodetic road supervision works (to observe geometry) and appropriate methods.

Methods

Research (surveying) was conducted in certain stretches of railway infrastructure. Only higher categories (I and II) roads, which need more careful supervision, were analysed in the research. More stringent requirements due to higher maximum speeds allowed are applied for them. Only roads between stations were selected because more favourable conditions affect their state and they are characterized by greater lengths. Selection criteria and five objects that match the collected data analysis are displayed in table 1 .

\begin{tabular}{|c|c|c|c|}
\hline & & Selection criteria & Other conditions \\
\hline \multirow{9}{*}{$\begin{array}{r}\text { Display of railway } \\
\text { road stretches } \\
\text { selected for the } \\
\text { research }\end{array}$} & \multirow{4}{*}{$\begin{array}{l}\text { Selected } \\
\text { stretch }\end{array}$} & At least $1 \mathrm{~km}$ long; & \multirow{4}{*}{$\begin{array}{l}\text { All stretches must have undergone } \\
\text { management (repair) process; }\end{array}$} \\
\hline & & Surveyed at least twice & \\
\hline & & Surveyed during different periods & \\
\hline & & $\begin{array}{l}\text { No repair works during the research not to disturb } \\
\text { the analysis data. }\end{array}$ & \\
\hline & \multirow{3}{*}{ Data } & Systems of coordinates and heights must correspond & \\
\hline & & Geometry and vertical profile data have survived & \multirow[t]{2}{*}{ To make comparisons } \\
\hline & & Primary project and surveying data can be found & \\
\hline & $\begin{array}{l}\text { Used } \\
\text { equipment }\end{array}$ & $\begin{array}{l}\text { Trimble SPS930, TopconHiper SR and Trimble } \\
\text { GEDO CE } 2 \text {. } \\
\text { Homogeneous and calibrated. Calibrated before } \\
\text { conducting geodetic surveying. }\end{array}$ & $\begin{array}{l}\text { Steady correction of devices is essential, } \\
\text { especially in winter and summer when } \\
\text { the temperature differences inside and } \\
\text { outside are highly noticeable. }\end{array}$ \\
\hline & $\begin{array}{l}5 \text { objects } \\
\text { were } \\
\text { selected: }\end{array}$ & $\begin{array}{l}\text { 1. } K-L 1 \mathrm{~km} \mathrm{I} \text { and II category road; } \\
\text { 2. } P-K 2.8 \mathrm{~km} \mathrm{II} \mathrm{category} \mathrm{road;} \\
\text { 3. } P-R-J 1.20 \mathrm{~km} \text { I category road; } \\
\text { 4. } P r-P 2.40 \mathrm{~km} \text { II category road; } \\
\text { 5. } \boldsymbol{V}-\check{Z} 1.30 \mathrm{~km} \mathrm{II} \mathrm{category} \mathrm{road.}\end{array}$ & \\
\hline
\end{tabular}


Trimble SPS930 electronic tachymeter was used in the research for complicated surveying and monitoring of constructions, railways, tunnels, etc. Multifunctional GNSS receiver TopconHiper SR and surveying trolley Trimble GEDO CE 2 were employed. Trimble GEDO CE 2 is employed for gauge geometry, size control and railway infrastructure. The trolley can survey roads which have gauges of different width by changing certain sections $(1000 \mathrm{~mm}, 1067 \mathrm{~mm}, 1435 \mathrm{~mm}, 1520 \mathrm{~mm}$, $1600 \mathrm{~mm}, 1668 \mathrm{~mm}, 1676 \mathrm{~mm}$, etc. according to special commission). The width of the gauge is surveyed. Its error gap ranges from $-20 \mathrm{~mm}$ to $+60 \mathrm{~mm}$. The error of the gauge width is $\pm 0.3 \mathrm{~mm}$. The width of the gauge is surveyed by entering the accurate surveyed distance (location), which is the starting point for calculation of subsequent surveying difference regarding the direction of press wheels. The distinction of the platform arrow is $\pm 10^{\circ}$ or $\pm 265 \mathrm{~mm}$. The accuracy of the platform is $\pm 0.5 \mathrm{~mm}$ (after point surveying). The platform is calculated according to the sensor where one can enter certain meanings or by turning the trolley twice during surveying and thus obtaining the average value, which is the subsequent starting point for evaluating the platform change according to the width of the gauge and inclination angle. Moreover, software GEDO Office, AutoCAD Civil 3D, Geosecma was used. The surveying equipment employed was sufficiently accurate if used correctly, inspected and regulated steadily. The equipment was checked and calibrated before starting geodetic surveying works following the requirements

The document regulating the use of railway, the basis of using $1520 \mathrm{~m}$ width gauge, the main surveying processes of constructions, equipment and rolling stock as well as requirements, maintenance standards, and principles of train traffic and signalizing is Regulations of the Technical Use of Railways (RTUR).

In order to pursue works, it is crucial to ask for vigilance warnings for trains concerning surveying by indicating the kilometres (points of works) and the anticipated period of works; during the preparation period temporary geodetic points are arranged and their surveying is conducted using GNSS receiver. Geodetic surveying (see Fig. 1) is conducted in the following way:

_ Coordination of two primary surveying stations using tachymeter and GNSS receiver within the distance of 500 metres.

Having built tachymeter on ST1, THE direction towards ST is entered and repetitive surveying is conducted. Thus the error of the distance is eliminated, which can be received by GNSS surveying;

The distance to benchmark 1 (BM1) is surveyed and railway surveying is conducted - 250 metres to both sides from the tachymeter are calculated, thus forming the section of 500 metres for railway surveying. During surveying the direction is checked every 250 metres (in the middle of surveying near the tachymeter and at the end of surveying at the control point) by turning the tachymeter to the already surveyed ST2 at the distance of 500 metres. If the direction does not correspond, it is restored and surveying is repeated;

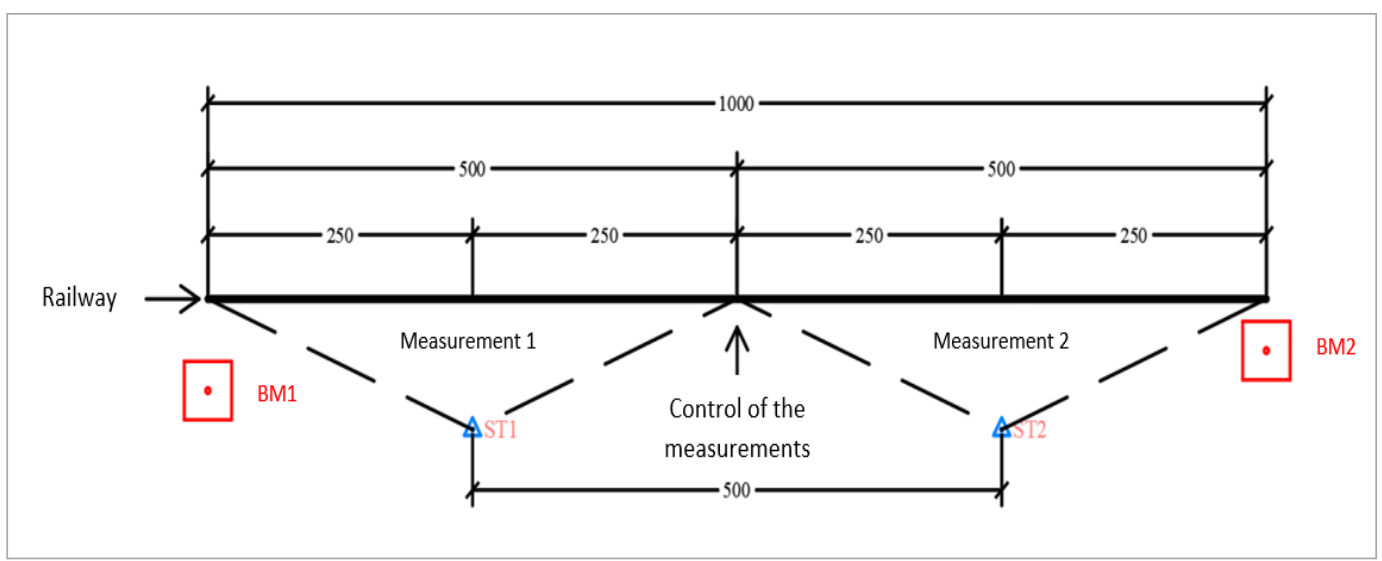

Fig. 1

The scheme of geodetic surveying technology 
Tachymeter is then brought to ST2. The distance to ST1 is surveyed and the direction and distances to benchmark2 (BM2) and ST3 are surveyed as well. The difference of surveying values $(X, Y, Z)$ is checked in surveying correspondence points;

Surveying is proceeded up to the final point in such a way.

Bench marks are arranged every kilometre. Two steady tachymeter stops ST1 and ST2 are equipped between them. In extreme cases, when it is very hot, shorter distances are retained between bench marks. The weather being hot, the number of surveying stops increases. Bench marks closest to tachymeter stops are surveyed. The distance not exceeding 500 metres between bench marks is retained. All data surveyed by tachymeters is transformed by changing the location and the altitude of tachymeter stops as well as by aligning hanging geodetic traverse.

Designing of road reconstruction is pursued using GEOSECMA software. Previously designed horizontal and vertical profiles were used in the research by entering their data and comparing it to the data of recent surveying.

In order to ensure railway traffic security, as well as environmental protection and reduction of risk factors for employees, strict rules and requirements are inevitable. One of important and little analysed stages of railway maintenance is identifying the state of the road according to the level, gauges and location in the plan. It must be systematically checked by transfer carriage by decoding recordings in the tape and evaluating deviations on the basis of road evaluation standards.

EM140 stores data in the closed data base, which is evaluated by responsible individuals (Savaeigio kelio..., 2012) of railway infrastructure. Having found defected spots of the road geometry, the order to conduct geodetic surveying is issued. On the basis of geodetic surveying findings, repair works are projected and conducted by road track tamping machines (09-32 CSM, 09-16 CSM, UNIMAT 08-475 4S), i.e. the road is repaired with regard to possibilities.

Geodetic surveying enables one to receive similar final data to that of road surveying machines EM140, 09-32 CSM, 09-16 CSM, UNIMAT 08-475 4S. However, methods of surveying data analysis and evaluation of findings significantly differ. Surveying machines conduct surveying (Geležinkelio...,2000) with regard to peculiarities of equipment and its possibilities, i.e. they identify differences when the distance is at least 18 metres. Meanwhile findings of geodetic surveying reveal differences even more frequently than every 18 meters and also reflect the changes from the starting point and/or geometry arrangement in the space during the analysed period. Data analysis obtained from surveying machines causes problems when evaluating road planning data and more abrupt width of inclination. Analysis of geodetic surveying does not have limitations of track evaluation. Geodetic equipment allows getting point surveying (when the road is surveyed every 5 meters). Are used the data of all. They are evaluated as the whole unity (straight lines, traverse and curve segments). Overall total deviation of the road is defined more precisely. Surveying machines cannot evaluate this fact. Thus, road surveying machine EM140, which declares high accuracy, can evaluate only the possibility of train passing in practice but it in any way does not identify total subsidence of the road or road deviations.

The aim of the research was to identify road deviation from the project data and compare geometry differences during different periods of time. All surveying was conducted before undertaking repair works. After surveying roads were restored to the project position. Systematized data provides maximum deviations of every stretch during the surveying period (table 2).

Horizontal deviation shows how much road axis has deviated from the project road axis (for instance, the deviation is $-167 \mathrm{~mm}$; it means that the road needs to be moved to the right by $167 \mathrm{~mm}$, i.e. $83.5 \mathrm{~mm}$, because at that time in the surveying place it has been distanced to the left). Vertical deviation shows how much the road needs to be lifted (for example, +51 the gauge reveals the discrepancy in mm of the distance between two railheads (it is supposed to be $1520 \mathrm{~mm}$ ). The platform shows how much one rail is higher than the other. 


\begin{tabular}{|c|c|c|c|c|c|}
\hline \multirow[b]{2}{*}{ Stretch } & \multirow[b]{2}{*}{$\begin{array}{l}\text { Surveying } \\
\text { data }\end{array}$} & \multicolumn{4}{|c|}{ Deviation from the original project, $\mathrm{mm}$} \\
\hline & & $\begin{array}{l}\text { Horizontal } \\
\text { deviation (- to the } \\
\text { left; + to the right) } \\
\text { from the project }\end{array}$ & $\begin{array}{l}\text { Vertical } \\
\text { deviation (+ is } \\
\text { missing from } \\
\text { the project) }\end{array}$ & Width of gauges & Platforms \\
\hline $\begin{array}{l}\mathrm{K}-\mathrm{L} 1 \mathrm{~km} \\
\text { I and II class road; }\end{array}$ & $\begin{array}{l}2016-08-23 \\
2016-11-14\end{array}$ & $\begin{array}{c}\text { | class || class } \\
-1 /+1-2 /+2 \\
-7 /-1 \quad-7 /-2\end{array}$ & $\begin{array}{c}\text { | class || } \\
\text { class }+51+38 \\
+34+38\end{array}$ & $\begin{array}{l}\text { I class || class } \\
-4 /+0-1 /+2 \\
-3 /+2-0 /+4\end{array}$ & $\begin{array}{ll}\text { I class } & \text { II class } \\
-4 /+8 & -21 /+0 \\
-5 /+6 & -23 /+0\end{array}$ \\
\hline $\begin{array}{l}\text { P-K } 3 \text { km } \\
\text { Il class road; }\end{array}$ & $\begin{array}{l}2014-09-04 \\
2017-07-19\end{array}$ & $\begin{array}{l}-167 /+73 \\
-203 /+81\end{array}$ & $\begin{array}{l}+113 \\
+113\end{array}$ & $\begin{array}{l}-4 /+9 \\
-4 /+8\end{array}$ & $\begin{array}{l}-8 /+10 \\
-5 /+6\end{array}$ \\
\hline $\begin{array}{l}\text { P-R-J } 1.20 \text { km } \\
\text { I class road; }\end{array}$ & $\begin{array}{l}2014-04-03 \\
2017-10-02\end{array}$ & $\begin{array}{l}-182 /+161 \\
-183 /+161\end{array}$ & $\begin{array}{l}+144 \\
+104\end{array}$ & $\begin{array}{l}-6 /+2 \\
-7 /+4\end{array}$ & $\begin{array}{l}-5 /+4 \\
-8 /+8\end{array}$ \\
\hline $\begin{array}{l}\text { Pr-P } 2.40 \text { km } \\
\text { II class road; }\end{array}$ & $\begin{array}{l}2014-09-17 \\
2017-10-26\end{array}$ & $\begin{array}{l}-190 /+155 \\
-95 /+182\end{array}$ & $\begin{array}{l}+91 \\
+41\end{array}$ & $\begin{array}{l}-5 /+5 \\
-2 /+4\end{array}$ & $\begin{array}{l}-5 /+9 \\
-0 /+8\end{array}$ \\
\hline $\begin{array}{l}\text { V-Ž } 2.40 \text { km } \\
\text { II class road; }\end{array}$ & $\begin{array}{l}2015-11-25 \\
2017-05-25\end{array}$ & $\begin{array}{l}-170 /+42 \\
-150 /+73\end{array}$ & $\begin{array}{l}+156 \\
+110\end{array}$ & $\begin{array}{l}-9 /-2 \\
-7 /+5\end{array}$ & $\begin{array}{l}-9 /+2 \\
-8 /+11\end{array}$ \\
\hline
\end{tabular}

Table 2

Maximum deviations in all stretches

By evaluating identified deviations, the criteria is taken into consideration (road gauges for geometry), set for surveying machine EM-140 (see table 3). According to these criteria, degree of deviations and maximum deviation limit of crucial speed reduction is defined. If the size of errors has reached IV degree of deviations, the speed of transport is supposed to be reduced down to a lower category. If deviations have reached IV degree and the road speed is reduced to $15 \mathrm{~km} / \mathrm{h}$, the road is closed. Currently the main way to conduct road geometry analysis is surveying by road machine. The machine defines the necessity to repair the rail road accurately enough in order to ensure appropriate railway traffic. Nevertheless, the obtained results do not provide the opportunity to evaluate the total change of railway condition or notice homogeneous subsidence of the road. The instruction of road geometric parameters evaluation K/259 (Savaeigio..., 2016) provides the limits that can be used analysing differences of short road segments (see table 3 ) but it is not suitable for evaluation of long segment deviations.

According to the findings of conducted surveying (see table 2), 3 stretches which have I degree deviation and 2 stretches having III degree deviation (tables 2-3) have been identified. The obtained data shows that the limits for width of gauges have not been exceeded. Such a tendency cannot be noticed even regarding differences of time periods. One can claim that 2 stretches have approached a must-repair stage in certain places or maximum projected speed must be reduced. However, they still meet compulsory criteria in order to maintain the necessary maximum speed and can be further exploited as roads of categories I and II. In general, road deviations depend on precision of the construction, which is ensured during the production process, rather than on the season or the period between road repair works.

Evaluating the planning road situation, $18 \mathrm{~m}$ length road segments are evaluated with help of surveying machines. Such analysis ensures train passage and correspondence of the road speed to the criteria. However, it cannot identify real road state correspondence to the original project. Road surveying machines are oriented towards analysis of the road state with regard to the perspective of a moving vehicle (because it analyses the state of the road when it is being used).

According to the data analysis, it is seen that sudden cases of road gauge damage in railway have been rare and mostly happen in the summer period. In such a way the road is closed and immediate repair works are pursued. In the research all evaluated stretches did not exceed the established geometry requirements for assurance of certain speed, taking into consideration the possibility for trains to run. 


\begin{tabular}{|c|c|c|c|c|c|c|c|c|c|c|c|c|c|c|c|c|c|}
\hline \multirow{10}{*}{$\begin{array}{r}\text { Table } 3 \\
\text { Limits of railway } \\
\text { road gauge width } \\
\text { and location in the } \\
\text { plan, limits of pits } \\
\text { and deviations. } \\
\text { (Savaeigio..., 2016) }\end{array}$} & \multirow{6}{*}{ 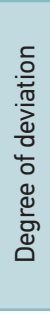 } & \multicolumn{16}{|c|}{ Limits of rail road } \\
\hline & & \multicolumn{4}{|c|}{ Width of gauges } & \multicolumn{4}{|c|}{ Location in the plan } & \multicolumn{4}{|c|}{ Pits } & \multicolumn{4}{|c|}{ Deviations } \\
\hline & & \multicolumn{16}{|c|}{ Road category and defined speed under deviations, $\mathrm{mm}$} \\
\hline & & \multicolumn{2}{|c|}{ I } & \multicolumn{2}{|c|}{ ॥ } & \multicolumn{2}{|c|}{ I } & \multicolumn{2}{|c|}{ II } & \multicolumn{2}{|c|}{ I } & \multicolumn{2}{|c|}{ II } & \multicolumn{2}{|c|}{ I } & \multicolumn{2}{|c|}{ ॥ } \\
\hline & & \multicolumn{2}{|c|}{$140 / 90$} & \multicolumn{2}{|c|}{$120 / 80$} & \multicolumn{2}{|c|}{$140 / 90$} & \multicolumn{2}{|c|}{$120 / 80$} & \multicolumn{2}{|c|}{$140 / 90$} & \multicolumn{2}{|c|}{$120 / 80$} & \multicolumn{2}{|c|}{$140 / 90$} & \multicolumn{2}{|c|}{$120 / 80$} \\
\hline & & + & - & + & - & + & - & + & - & + & - & + & - & + & - & + & - \\
\hline & I & 8 & 4 & 8 & 4 & 5 & 5 & 5 & 5 & 8 & 4 & 8 & 4 & 5 & 5 & 5 & 5 \\
\hline & $\|$ & 14 & 6 & 14 & 6 & 7 & 7 & 12 & 12 & 14 & 6 & 14 & 6 & 7 & 7 & 12 & 12 \\
\hline & III & 16 & 8 & 16 & 8 & 12 & 12 & 17 & 17 & 16 & 8 & 16 & 8 & 12 & 12 & 17 & 17 \\
\hline & IV & $>16$ & $<8$ & $>16$ & $<8$ & $>12$ & $<12$ & $>17$ & $<17$ & $>16$ & $<8$ & $>16$ & $<8$ & $>12$ & $<12$ & $>17$ & $<17$ \\
\hline
\end{tabular}

General deviations of road geometry were observed rather than single road deformations. Geometry changes have significant impact when curves are being evaluated. However, none of them did not decrease up to the point when the speed of the train must be reduced. On the other hand, if comparing the restored road geometry with initial project data, discrepancies can be noticed. In this case the limit of discrepancies was highly exceeded. As a result, the problem arises when evaluating such situations, namely, actual road characteristics show that the road is suitable for exploitation. However, the road does not meet the initial geometry and is suitable for use only due to additional reserved distances. When evaluating maximum discrepancies to the project, one can see the values exceeding the momentum of $150 \mathrm{~mm}$, which, regarding exploitation characteristics of the train, in practice limits the possibility to manage with one tamping (road repair). In order to conduct correction of the horizontal profile adequately, it is best to use momenta not exceeding $100 \mathrm{~mm}$.

The majority of roads exceed practical characteristics of one tamping. The only road that has retained its characteristics was tamped every 2 months while all other roads after 1.5 years of exploitation required repair works again. Having exceeded 1.5 years' period, roads typically require repair and, thus, one can claim that it is crucial to organize surveying more often than the period mentioned (see table 2).

Evaluating the change of longitudinal profile, frequent pits were found. The analysis helped to notice that railway road construction tends to subside in points of inclination intersections. Regarding time, profile and designing tendencies, it has been found that even under similar exploitation conditions certain places have tendencies for pits to form. This situation is best evaluated by conducting geodetic surveying.

After surveying, the data is used to find a solution to the problem. It allows defining accurate height and frequency of railway tamping. Geodetic surveying in this case not only defines the size of the pit more precisely but also ensures complete restoration. Surveying and repair machines can record only larger pits because they have no possibilities to survey them using the laser or the string. When defects are evaluated according to the table by the road machine, the surveying distance is 5.4 metres. Analysing at such a distance III and IV degree road deviations were identified. It means that the speed must be reduced for roads of category IV whereas repair works have to be planned for category III roads. 2.5 months after the last correction of the road the need for repair was identified. Analysing other stretches, it was discovered that after 3 years damaged stretches containing the same aforementioned defects emerged. Although the road is still suitable for exploitation, the speed in its segments has to be reduced. Thus, additional risk forms because the road loses qualities of speed and stability. 


\begin{tabular}{|c|c|c|c|}
\hline \multirow{3}{*}{ Stretch } & \multirow{3}{*}{$\begin{array}{l}\text { Date of the } \\
\text { measurements }\end{array}$} & \multicolumn{2}{|c|}{ Issues of vertical profile } \\
\hline & & \multicolumn{2}{|c|}{ Inadequacies in the project } \\
\hline & & I category & II category \\
\hline \multirow{2}{*}{$\begin{array}{l}\text { Kaišiadorys - Livintai } \\
1 \text { km I ir II road; }\end{array}$} & 2016-08-23 & $\begin{array}{l}51 \mathrm{~mm} 70 \mathrm{~m} \\
35 \mathrm{~mm} 300 \mathrm{~m}\end{array}$ & $\begin{array}{c}28 \mathrm{~mm} 40 \mathrm{~m} \\
35 \mathrm{~mm} 100 \mathrm{~m} \\
38 \mathrm{~mm} 40 \mathrm{~m} \\
27 \mathrm{~mm} 60 \mathrm{~m}\end{array}$ \\
\hline & $2016-11-14$ & $35 \mathrm{~mm} 200 \mathrm{~m}$ & $\begin{array}{c}22 \mathrm{~mm} 20 \mathrm{~m} \\
32 \mathrm{~mm} 100 \mathrm{~m} \\
38 \mathrm{~mm} \mathrm{40m} \\
25 \mathrm{~mm} \mathrm{40m}\end{array}$ \\
\hline $\begin{array}{l}\text { Palemonas - Kaunas } \\
\text { 2,8 km II road; }\end{array}$ & 2014-09-04 & & $\begin{array}{c}60 \mathrm{~mm} 80 \mathrm{~m} \\
32 \mathrm{~mm} 70 \mathrm{~m} \\
70 \mathrm{~mm} \mathrm{640m} \\
47 \mathrm{~mm} 200 \mathrm{~m} \\
65 \mathrm{~mm} \mathrm{100m} \\
76 \mathrm{~mm} \mathrm{200m} \\
113 \mathrm{~mm} 480 \mathrm{~m} \\
73 \mathrm{~mm} \mathrm{240m}\end{array}$ \\
\hline \multirow{4}{*}{ Stretch } & \multirow{3}{*}{$\begin{array}{l}\text { Date of the } \\
\text { measurements }\end{array}$} & \multicolumn{2}{|c|}{ Issues of vertical profile } \\
\hline & & \multicolumn{2}{|c|}{ Inadequacies in the project } \\
\hline & & I category & II category \\
\hline & 2017-07-19 & & $\begin{array}{c}67 \mathrm{~mm} 220 \mathrm{~m} \\
60 \mathrm{~mm} 500 \mathrm{~m} \\
64 \mathrm{~mm} \mathrm{120m} \\
33 \mathrm{~mm} 110 \mathrm{~m} \\
59 \mathrm{~mm} 90 \mathrm{~m} \\
73 \mathrm{~mm} \mathrm{160m} \\
113 \mathrm{~mm} \mathrm{490m} \\
70 \mathrm{~mm} \mathrm{220m}\end{array}$ \\
\hline \multirow[t]{2}{*}{$\begin{array}{l}\text { Palemonas - Rokai - Jiesia } \\
\text { 1,20km I road; }\end{array}$} & 2014-04-03 & $\begin{array}{c}59 \mathrm{~mm} 200 \mathrm{~m} \\
82 \mathrm{~mm} \mathrm{140m} \\
44 \mathrm{~mm} 120 \mathrm{~m} \\
59 \mathrm{~mm} 140 \mathrm{~m} \\
26 \mathrm{~mm} 30 \mathrm{~m} \\
144 \mathrm{~mm} 200 \mathrm{~m}\end{array}$ & \\
\hline & 2017-10-02 & $\begin{array}{c}29 \mathrm{~mm} \mathrm{40m} \\
63 \mathrm{~mm} 370 \mathrm{~m} \\
68 \mathrm{~mm} 230 \mathrm{~m} \\
104 \mathrm{~mm} 220 \mathrm{~m}\end{array}$ & \\
\hline \multirow[t]{2}{*}{$\begin{array}{l}\text { Pravieniškès - Palemonas } \\
\text { 2,40km II road; }\end{array}$} & 2014-09-17 & & $\begin{array}{c}30 \mathrm{~mm} \mathrm{20m} \\
40 \mathrm{~mm} \mathrm{140m} \\
29 \mathrm{~mm} 80 \mathrm{~m} \\
37 \mathrm{~mm} \mathrm{10m} \\
91 \mathrm{~mm} \mathrm{1350m}\end{array}$ \\
\hline & $2017-10-26$ & & $\begin{array}{l}30 \mathrm{~mm} 120 \mathrm{~m} \\
41 \mathrm{~mm} 260 \mathrm{~m} \\
37 \mathrm{~mm} 120 \mathrm{~m}\end{array}$ \\
\hline \multirow[t]{2}{*}{$\begin{array}{l}\text { Vievis - Žasliai } \\
\text { 1,30km II road; }\end{array}$} & $2015-11-25$ & & $\begin{array}{c}64 \mathrm{~mm} \mathrm{240m} \\
122 \mathrm{~mm} \mathrm{460m} \\
93 \mathrm{~mm} 210 \mathrm{~m} \\
156 \mathrm{~mm} 200 \mathrm{~m}\end{array}$ \\
\hline & $2017-05-25$ & & $\begin{array}{l}35 \mathrm{~mm} \mathrm{140m} \\
110 \mathrm{~mm} \mathrm{1100m}\end{array}$ \\
\hline
\end{tabular}

\section{Table 4}

Problematic areas of vertical profile 
When evaluating the state of the road on the basis of platform discrepancy with the project, the average $8 \mathrm{~mm}$ platform discrepancy was identified while following the standards in straight stretches it is supposed not to exceed $6 \mathrm{~mm}$. Taking into consideration the general situation, the highest deviations occur at intervals and have no common dependence for the whole stretch but rather emerge in single spots. Regarding the periods of time, all the stretches that were analysed were close or even slightly exceeded level IV of the deviation (see table 4). One can claim that is reasonable to observe the road state more frequently than 1.5 years despite the fact that road exploitation is still possible. There were cases when monitoring showed that even after 3 years of exploitation no repair works were necessary. $K-L$ road segment is exceptional where II category road even after repair works regained the platform of emergency condition within the period of 2 months. Therefore, repeated surveying and monitoring were indispensable. Nevertheless, such cases are rare and they depend on the state of slopes or ground compaction.

Having reviewed the obtained data, it was found that analysis of railway road construction was not sufficient. The shortage of archive data of the previously conducted surveying was found. It could be used for monitoring and maintenance. Road surveying equipment in the train can roughly identify the state of the road and ensure road safety. However, it cannot evaluate the state of the whole road. Steady and renewed regulations are essential for road state observation and repair. It is suggested to pursue railway surveying straight after road repair and 2-3 months after so that steadiness of road state could be evaluated. Regular schedule of geodetic surveying supervision should be designed whereas if needed, surveying could be more frequent. Road surveying should be conducted once per year on average. The most significant problems are observed after 2 months. Currently the road is supervised by identifying the defects by surveying machine. Afterwards geodetic surveying is conducted on the basis of data analysis. Such a solution allows ensuring minimum compulsory maintenance but it does not provide the possibility to create more favourable conditions for repair and analysis. Thus, there is a problem to design road repair schedule and work usually is organized urgently rather than planning in advance. Not only is the state of the stretch different but also each stretch kilometre wears differently. In each situation one has to make individual decisions.

Fig. 2

The proposed railway control measurement technology model

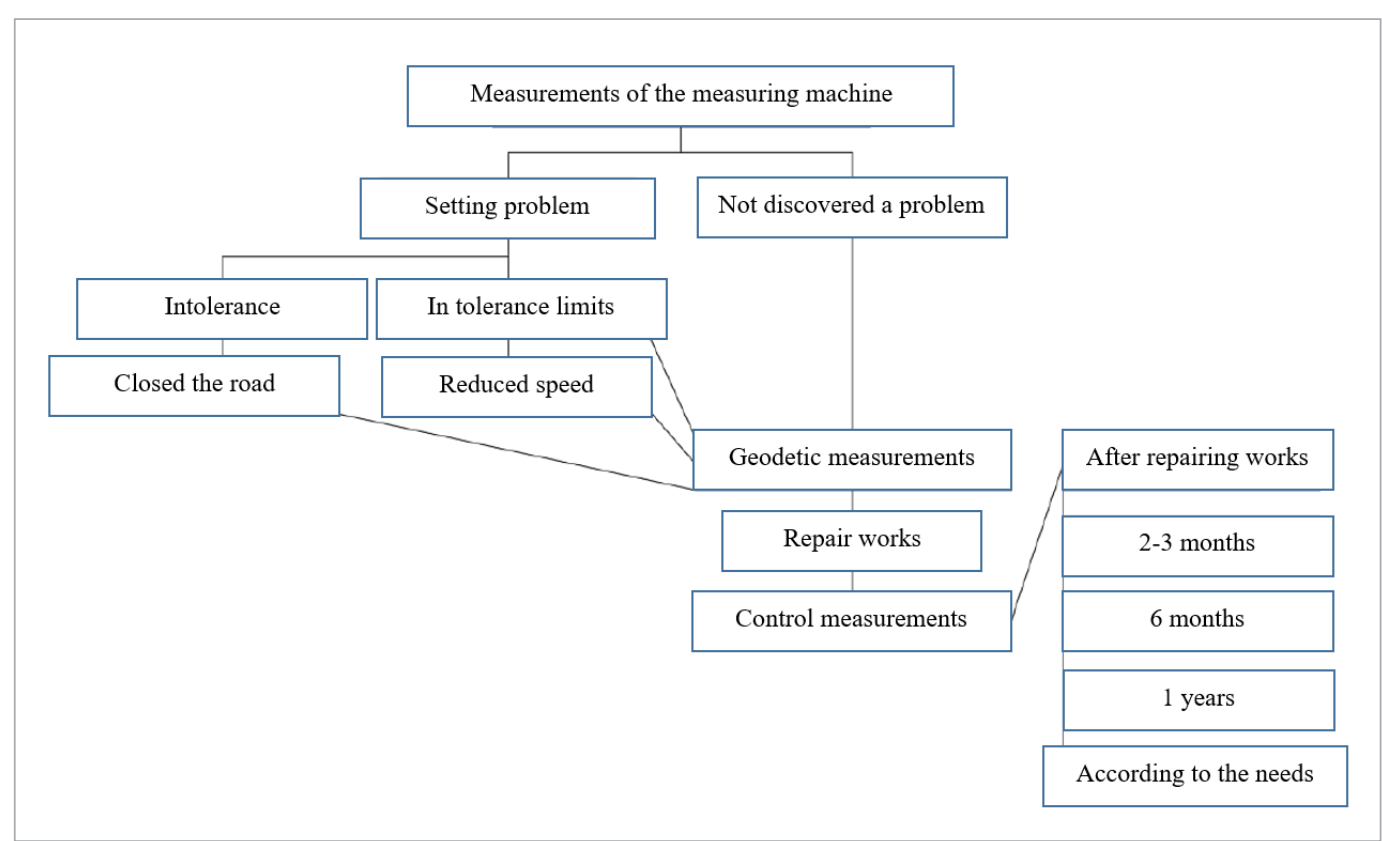


All things considered, one can claim that the state of roads tends to deteriorate although it does not depend on time. It is more affected by the initial project, road exploitation and quality of repair works. In order to ensure fully-fledged supervision of the road state, it is important to conduct surveying more frequently by using geodetic equipment. In such a way not only the possibility of train passing could be evaluated but also initial road characteristics could be preserved and their original place could be restored. Having conducted and evaluated research findings, there is a suggestion to pursue surveying straight after repair works. The proximate surveying should be organized no later than 2-3 years after to check the tendencies of road state change (road deviations from the initial state). Subsequent actions could be surveying at least once per year. If the state of the road is steady during the first months, surveying could be conducted once per year. If higher deviations are observed, more frequent surveying would allow detect causes of damage and repair the road until defects do not significantly affect road exploitation.

1 The width of the gauge is the least changing factor, which is characterized by rare, more individual and short sections (-7/+9). Replacement of the road platform has more significant impact, which is harder to detect without special equipment though it is of crucial importance in order to ensure safety for trains moving at high speeds, especially in curves. In rare cases higher replacement of the platform occurs related to railway bed or the state of the pad $(-8 /+11)$. Scheduled tracks and repair of vertical profile require steady supervision as it changes most often and needs correction of 100-200 mm horizontal profile, $100 \mathrm{~mm}$ vertical profile, which exceeds the limits of regular one-time correction.

2

The main problems faced are as follows: shortage of regulations defining precise requirements applied for the width of $1520 \mathrm{~mm}$ gauges in roads and regulating the procedure of geodetic surveying and parameters, which are used to evaluate the road and actions; geodetic surveying conducted the wrong time and the tendency to solve problems when the limits of deviations and errors have been exceeded; the lack of specialists in narrow specialization; the lack of favourable conditions for data collection and storage.

3 It is suggested to conduct more frequent surveying of the road straight after repair works. 3 In order to test the tendencies of road state change the subsequent surveying should be planned and conducted no later than in 2-3 months. Regular schedule of geodetic surveying supervision should be designed. If necessary, surveying could be organized more frequently. Otherwise surveying is supposed to be conducted on average once per year.

Andrade A. R. Renewal decisions from a Lifecycle Cost (LCC) perspective in Railway Infrastructure: An integrative approach using separate LCC models for rail and ballast components. Thesis in Civil Engineering, Technical University of Lisbon. Lisbon, 2008

Aursudkij B. A Laboratory Study of Railway Ballast Behaviour under Traffic Loading and Tamping Maintenance. PhD thesis. University of Nottingham, 2007.

Aursudkij B., McDowell G. R., Collop A. C. Cyclic loading of railway ballast under triaxial conditions and in a railway test facility. Granular Matter, 2009, No 11. p. 391-401. https://doi.org/10.1007/s10035009-0144-4

Brown S. F., Brodrick B. V., Thom N. H., McDowell G. R. The Nottingham Railway Test Facility, 2007.
Proceedings of the Institution of Civil Engineers Transport Volume 160, Issue 2, p.59-65. https://doi. org/10.1680/tran.2007.160.2.59

Gailienè I., Podagèlis I. Evaluation of the track superstructure of Lithuanian railway lines calculating characteristics of strength. The 7th International Conference "Environmental engineering". Selected papers. Vol. 3. Ed. by D. Čygas, K. D. Froehner, May 22-23, 2008, Vilnius, Lithuania. Vilnius: Technika, 2008; p. 1146-1153.

Geležinkelio kelio priežiūros taisyklès [Rules of the railways maintenance]. K/111, 2000. Vilnius: Leidybos centras (in Lithuanian).

Grimes C. A. Application of genetic techniques to the planning of railway track maintenance work. Conference on Genetic Algorithms in Engineering

\section{Conclusions}

\section{References}


Systems: Innovations and Applications. GALESIA. IEE: Sheffield, UK, 414, 1995; p. 467-472. https:// doi.org/10.1049/cp:19951093

Jovanovic S. (2004) Railway track quality assessment and related decision making. The 2004 IEEE international conference on systems, man and cybernetics. The Hague, The Netherlands Vol. 6. 2004; p. 5038-5043. https://doi.org/10.1109/ ICSMC.2004.1400992

Lackenby J. (2006) Triaxial behavior of ballast and the role of confining pressure under cyclic loading. $\mathrm{PhD}$ thesis. University of Wollongong.

Prokopimas Š. (2017) Šiuolaikiniai geležinkelių matavimo metodai pasitelkus "Trimble GEDO". Available at http://www.darnistatyba.lt/gelezinkeliu-ma- tavimo-metodai-trimble-gedo-vorsys-iranga/ (in Lithuanian).

Savaeigio kelio matavimo vagono EM1-140 matuojamų geležinkelio kelio geometrinių parametru jvertinimo instrukcija [Instructions for assessing track geometric parameters measured on the self-propelled road wagon EM1-140] K/259, 2016. Patvirtinta $A B$ "Lietuvos geležinkeliai" generalinio direktoriaus 2012 m. sausio 4 d. isakymu Nr. l-10 (in Lithuanian).

Skrinskas S., Gasiūnienè V. E., Laurinavičius A., Podagèlis I. Lithuanian Mineral Resources, Their Reserves and possibilities for Their Usage in Road Building. The Baltic Journal of Road and Bridge Engineering. No 5 (4), 2010; p. 218-228.

\section{About the DONATAS REKUS}

\section{Authors Doctor of technology science, Assoc. prof,}

Kaunas University of technology, Faculty of Civil Engineering and Architecture

\section{Main research area}

Calibration of geodetic instruments, height measurements, geodetic scanning technologies

\section{Address}

Studentu str. 48-418,

Kaunas LT-51367, Lithuania,

Tel. +370 37300479 ,

E-mail: donatas.rekus@ktu.lt

\section{VILMA KRIAUČIŪNAITĖ-NEKLEJONOVIENE்}

Doctor of technology science, lecturer

Kaunas University of technology, Faculty of Civil Engineering and Architecture

\section{Main research area}

Geodesy, rural development, land-use management, real estate management

\section{Address}

Studentu str. 48-414, Kaunas LT-51367, Lithuania, Tel. +370 37300479 ,

E-mail: vilma.kriauciunaite@ktu.lt 